\title{
Erratum to: Adjuvant Radioactive iodine 131 ablation in papillary microcarcinoma of thyroid: Saudi Arabian experience
}

Khalid Hussain AL-Qahtani ${ }^{1}$, Mushabbab Al Asiri ${ }^{2}$, Mutahir A. Tunio ${ }^{2 *}$, Naji J. Aljohani ${ }^{3}$, Yasser Bayoumi ${ }^{4}$,

Hanadi Fatani ${ }^{5}$ and Abdulrehman AlHadab ${ }^{6}$

Unfortunately, the original version of this article [1] contained two errors. The title incorrectly referred to "radioactive iodine 133" instead of "radioactive iodine 131" and contained unnecessary quotation marks.

The title has been updated in the original article and is also correctly included in full in this erratum.

\begin{abstract}
Author details
'Department of Otolaryngology-Head \& Neck Surgery, College of Medicine, King Saud University, Riyadh, Saudi Arabia. ${ }^{2}$ Radiation Oncology,

Comprehensive Cancer Center, King Fahad Medical City, Riyadh 59046, Saudi Arabia. ${ }^{3}$ Endocrinology and thyroid Oncology, King Fahad Medical City,

Riyadh 59046, Saudi Arabia. ${ }^{4}$ Radiation Oncology, NCl, Cairo University, Cairo, Egypt. ${ }^{5}$ Histopathology, King Fahad Medical City, Riyadh 59046, Saudi Arabia.

${ }^{6}$ Radiation Oncology, King AbdulAziz University, Riyadh 59046, Saudi Arabia.
\end{abstract}

Received: 26 January 2016 Accepted: 26 January 2016

Published online: 29 January 2016

\section{Reference}

1. Al-Qahtani KH, Al Asiri M, Tunio MA, Aljohani NJ, Bayoumi Y, Fatani H, et al. Adjuvant Radioactive iodine 131 ablation in papillary microcarcinoma of thyroid: Saudi Arabian experience. J Otolaryngol Head Neck Surg. 2015;44:51.

* Correspondence: drmutahirtonio@hotmail.com

${ }^{2}$ Radiation Oncology, Comprehensive Cancer Center, King Fahad Medical City, Riyadh 59046, Saudi Arabia

Full list of author information is available at the end of the article

Submit your next manuscript to BioMed Central and we will help you at every step:

- We accept pre-submission inquiries

- Our selector tool helps you to find the most relevant journal

- We provide round the clock customer support

- Convenient online submission

- Thorough peer review

- Inclusion in PubMed and all major indexing services

- Maximum visibility for your research

Submit your manuscript at www.biomedcentral.com/submit (c) 2016 AL-Qahtani et al. Open Access This article is distributed under the terms of the Creative Commons Attribution 4.0 International License (http://creativecommons.org/licenses/by/4.0/), which permits unrestricted use, distribution, and reproduction in any medium, provided you give appropriate credit to the original author(s) and the source, provide a link to the Creative Commons license, and indicate if changes were made. The Creative Commons Public Domain Dedication waiver (http://creativecommons.org/publicdomain/zero/1.0/) applies to the data made available in this article, unless otherwise stated. 